Volume 4 Nomor 2 Oktober 2020

e-ISSN: 2549-9114 dan p-ISSN: 2549-9203

(Received: April-2020; Reviewed: Agustus-2020; Published: Oktober-2020)

https://doi.org/10.26858/pembelajar.v4i2.13559

\title{
Pengembangan E-Module Berbasis Problem Based Learning Mata Pelajaran Ekonomi Kelas X SMA Negeri 1 Percut Sei Tuan Tahun Ajaran 2018/2019
}

\author{
Pebri Hastuti $^{\mathrm{a}}$, Roza Thohiri ${ }^{\mathrm{a}}$, Yanti Panggabean ${ }^{\mathrm{b}}$ \\ aUniversitas Negeri Medan \\ ${ }^{b}$ Universitas Negeri Medan
}

Corresponding e-mail: pebrihastuti06@gmail.com, rozathohiri@gmail.com, yantipanggabean@gmail.com

Abstrak: $\quad$ Penelitian ini bertujuan untuk (1) menghasilkan e-module yang tepat sebagai media pembelajaran berbasis problem based learning untuk kelas X (2) mengetahui kelayakan e-module dengan berpedoman pada kriteria bahan ajar yang ditentukan oleh Depdiknas, (3) mengetahui hasil evaluasi siswa kelas X setelah menggunakan e-module bebasis problem based learning. Penelitian ini merupakan jenis penelitian pengembangan R\&D (Research and Development) dengan mengacu pada model pengembangan ADDIE meliputi Analysis (Analisis), Design (Desain/Perancangan), Development (Pengembangan), Implementation (Implementasi), Evaluation (Evaluasi). Subjek penelitian ini meliputi 2 dosen ahli media, 1 dosen dan 1 guru mata pelajaran ahli materi, dan siswa kelas X SMA Negeri 1 Percut Sei Tuan. Objek penelitian ini berupa $e$-module pembelajaran. Instrumen yang digunakan untuk menilai kelayakan $e$ module meliputi lembar penilaian kelayakan oleh ahli materi, lembar penilaian kelayakan oleh ahli media, dan angket respon siswa terhadap penggunaan e-module. Hasil penelitian menunjukkan (1) e-module pembelajaran yang dikembangkan menjadi E-Module Konsep Manajemen Bebasis Problem Based Learning untuk siswa kelas X, (2) e-module yang dikembangkan dinyatakan layak dengan perolehan ratarata skor oleh ahli materi sebesar 3,46, ahli media sebesar 3,19, dan oleh respon siswa sebesar 3,19 sehingga kelayakan e-module yang dikembangkan termasuk dalam kategori "Sangat Baik", (2) hasil evaluasi belajar siswa diperoleh persentase $85,71 \%$ pada kategori kriteria keberhasilan tinggi.

Kata Kunci: Pengembangan, E-Module, Problem Based Learning

Abstract: $\quad$ This study aims to: (1) produce appropriate e-modules as problem based learning media for class X (2) determine the feasibility of e-modules by referring to the teaching material criteria specified by the Ministry of National Education, (3) knowing the evaluation results Class X students after using the e-module based on problem based learning. This research is a type of research development of R\&D (Research and Development) with reference to the ADDIE development model including Analysis, Design, Development, Implementation, Evaluation. The subjects of this study include 2 media expert lecturers, 1 lecturer and 1 subject matter expert teacher, and class X students of SMA Negeri 1 Percut Sei Tuan. The object of this study is the e-module learning instruments used to assess the feasibility of e-modules include the eligibility assessment sheet by material experts, the eligibility assessment sheet by media experts, and student questionnaire responses to the use of e-modules. The results showed (1) e-module learning developed into E-Module Concept Management Based On Problem Based Learning for class X students, (2) the e-module developed was declared to be feasible with the average score obtained by material experts at 3.46 , media experts amounted to 3.19 , and by student responses amounted to 3.19 so that the feasibility of the developed e-module was included in the "Very Good" category, (2) the results of student learning evaluations obtained a percentage of $85.71 \%$ in the high success criteria category.

Keywords: Development, E-Module, Problem Based Learning Activity

C2020-Ini adalah artikel dengan akses terbuka dibawah licenci CC BY-NC-4.0

(https://creativecommons.org/licenses/by-nc/4.0/ ) by penulis. 
Pebri Hastuti, Roza Thohiri, Yanti Panggabean. Pengembangan E-Module Berbasis Problem Based Learning Mata Pelajaran Ekonomi Kelas X SMA Negeri 1 Percut Sei Tuan Tahun Ajaran 2018/2019

\section{PENDAHULUAN}

Proses pendidikan merupakan suatu sistem yang terdiri dari input, proses dan output. Input disini merupakan peserta didik yang akan melaksanakan aktivitas belajar, proses merupakan kegiatan selama belajar mengajar sedangkan output merupakan hasil dari proses pembelajaran yang dilaksanakan. (Hutasuhut \& Syahfitri, 2018). Perkembangan ilmu pengetahuan dan teknologi semakin mendorong upaya-upaya pembaharuan dalam pemanfaatan hasil-hasil teknologi dalam proses belajar. Kemajuan di bidang teknologi pendidikan menuntut digunakannya media pembelajaran elektronik. Oetomo (dalam Dwiki 2014:49) menyatakan bahwa salah satu bidang yang mendapatkan dampak yang cukup berarti dengan perkembangan teknologi ini adalah bidang pendidikan, di mana pada dasarnya pendidikan merupakan suatu proses komunikasi dan informasi dari pendidik kepada peserta didik yang berisi informasi-informasi pendidikan, yang memiliki unsur-unsur pendidik sebagai informasi, media sebagai sarana penyajian ide, gagasan dan materi pendidikan, serta peserta didik itu sendiri. Pemanfaatan teknologiyang kuran tepat dikalangan pendidik maupun peserta didik dapat menimbulkan kesulitan belajar tersendiri bagi mahasiswa. Hal ini sesuai dengan pernyataan yang menyatakan "Deficiency of learning discipline and a bad school environment trigger increased student learning difficulties"(Hastuti et al., 2015)

Dewasa ini dunia pendidikan hidup dalam dunia media, dimana kegiatan pembelajaran yang secara konvesional yang lebih mengedepankan metode ceramah diganti dengan system penyampaian bahan ajar yang lebih modern yang lebih mengedepankan peran siswa dengan pemanfaatan media. Perkembangan teknologi informasi beberapa tahun belakangan ini berkembang dengan kecepatan yang sangat tinggi, sehingga dengan perkembangan ini telah mengubah paradigma setiap orang dalam mencari dan mendapat informasi. (Darmawan, 2014: 61). Dengan adanya perkembangan ini akan memberikan dampak yang sangat signifikan dalam mendidik dan mencerdaskan kehidupan bangsa.

Salah satu inovasi kreatif dari perkembangan ilmu pengetahuan dan teknologi yaitu lahirnya konsep e-learning . Secara harfiah, E-learning terdiri dari dua bagian yaitu singkatan dari $\mathrm{E}$ atau elektronika dan Learning yang berarti pembelajaran. Sehingga, E-learning berarti pembelajaran dengan menggunakan jasa bantuan perangkat elektronik. Konsep pembelajaran ini memudahkan siswa dan guru dalam memperoleh sumber belajar dengan akses yang ringan. Berbeda dengan kegiatan pembelajaran konvesional yang lebih mengedepankan metode ceramah, menitik beratkan materi pada penguasaan seorang guru. $E$ learning adalah salah satu hasil perkembangan teknologi informasi dan komunikasi di dunia pendidikan yang sangat efektif dalam pencapaian tujuan pembelajaran.

Menurut Hannay (dalam Nelvi 2015:18) secara teori e-learning adalah sesuatu yang menarik, hal ini dikarenakan sudah banyak institusi pendidikan yang melengkapi proses pembelajarannya dengan penerapan e-learning . Sehingga sangat banyak keuntungan dengan menggunakan konsep $e$ learning dibandingkan menggunakan sistem konvensional. Kegiatan pembelajaran konvensional di dalam kelas memang tidak bisa ditinggalkan, namun guru perlu memberikan variasi-variasi pembelajaran untuk meningkatkan hasil belajar siswa.

Pada kegiatan pembelajaran di dalam kelas, seharusnya guru hanya berperan sebagai fasilitator, sedangkan peserta didik harus belajar secara mandiri serta membangun pengetahuannya sendiri agar mereka mudah untuk memahami materi. Pemanfaatan modul sebagai salah satu sumber belajar bagi mahasiswa diharapkan mampu meningkatkan hasil belajarnya. Hal ini senada dengan pendapat Roza Thohiri dalam sebuah seminar internasional yang menyatakan bahwa pemanfaatan learning modul khususnya dalam penerapan dengan pendekatan PBL akan mampu meningkatkan kompetensi siswa(Cleary, 2019)

Penggunaan media elektronik sebagai media pembelajaran sudah diterapkan oleh berbagai lembaga pendidikan namun belum merata secara keseluruhan, salah satu nya adalah penggunaan emodule atau lebih dikenal dengan modul elektronik.

E-module merupakan bahan ajar yang dapat membantu siswa dalam mempelajari materi pelajaran secara mandiri yang dalam penggunaannya menggunakan media elektronik. $E$ Module dapat membantu guru dalam menjelaskan materi pelajaran yang akan dijelaskan. E-Module memiliki peran penting dalam pembelajaran. Pembelajaran dapat berlangsung secara efektif apabila menggunakan e-module karena dapat membantu siswa yang mengalami kesulitan dalam belajar.

Wenno (dalam Komang 2017:41) mengungkapkan bahwa untuk menyediakan bahan ajar yang sesuai dengan perkembangan zaman, maka bisa dibantu dengan pemberian modul ajar, 
sebuah modul ajar akan bermakna, jika siswa dapat dengan mudah menggunakannya. Adapun modul ajar yang sekarang sesuai dengan perkembangan teknologi adalah berbasis elektronik yang sering disebut e-module.

Berdasarkan hasil observasi yang peneliti lakukan di SMA Negeri 1 Percut Sei Tuan pada 1 Februari 2018, bahan ajar dalam proses pembelajaran masih terbatas. Siswa hanya menggunakan buku paket pada saat proses pembelajaran. Buku paket tersebut merupakan buku terbitan penerbit. Buku paket yang digunakan dalam kegiatan pembelajaran merupakan bahan ajar yang masih bersifat umum, belum disajikan secara rinci serta masih bersifat konvensional dalam penggunaannya atau disajikan dalam bentuk cetak. Penyajian materi dan soal-soal latihan pada buku paket masih banyak yang tidak sesuai dengan kenyataan yang dihadapi para siswa sehingga menjadi hambatan bagi siswa dalam mengelola kemampuannya memahami pembelajaran.

Berdasarkan hasil wawancara peneliti dengan seorang guru bidang studi Ekonomi Ibu Desnawati Ginting,S.Pd bahwa bahan ajar yang digunakan selama ini dalam pelajaran ekonomi di kelas X-IPS adalah buku paket dari pemerintah atau dari dana BOS. Siswa tidak diberikan bahan ajar lain seperti modul, lembar kerja siswa/ LKS dan handout sebagai sumber belajar. Hal ini membuat hasil belajar siswa di SMA Negeri 1 Percut Sei Tuan rendah. Kriteria ketuntasan minimal (KKM) mata pelajaran ekonomi yaitu 75 (tujuh puluh lima). Persentase hasil belajar siswa yang mencapai nilai di atas KKM atau $\geq 75$ yaitu $40 \%$, ini berarti menunjukkan bahwa hasil belajar siswa masih tergolong rendah.

SMA Negeri 1 Percut Sei Tuan adalah sekolah yang telah mengimplementasikan kurikulum 2013. Sekolah ini juga terpilih menjadi salah satu sekolah rujukan. Sebagai sekolah rujukan, e-module merupakan salah satu program yang dicanangkan. Jadi tidak salah apabila peniliti memilih sekolah ini sebagai objek penelitian sebagi tempat untuk mengembangkan e-modul. Daryanto (2013) mengungkapkan bahwa e-module yang baik adalah memiliki karakteristik yang sama dengan modul. Adapun karakteristik e-module adalah self intruction yaitu intruksi yang memudahkan siswa mengetahui tujuan pembelajaran yang akan dicapai, self contained yaitu materi-materi yang disajikan dalam pembelajaran, stand alone yaitu emodule harus berdiri sendiri tanpa bergantung pada bahan lain, adatif yaitu sesuai dengan perkembangan ilmu pengetahuan dan teknologi, dan user friendly yaitu e-module yang dapat membantu dan bersahabat dengan pemakainya.

Oleh karena itu, e-modul sebagai bahan ajar dapat membantu siswa untuk belajar secara mandiri memiliki bahasa yang komunikatif dan bersifat dua arah sehingga memudahkan siswa dalam mempelajari materi pelajaran juga dapat membantu siswa mengukur tingkat pemahamannya sendiri. Pembelajaran dapat berlangsung secara efektif apabila menggunakan e-modul karena dapat membantu siswa yang mengalami kesulitan belajar dan juga meningkatkan hasil belajar siswa.

Menurut penelitian sebelumnya Nelvy (2015), diperoleh nilai rata-rata pretes 58,28 dan setelah diberi perlakuan menggunakan e-modul ekonomi hasil belajar siswa meningkat dengan nilai rata-rata 82,34. Selain itu hasil penelitian Evi (2018) diperoleh nilai rata-rata sebelum menggunakan emodul 64,44 dan setelah menggunakan e-modul hasil belajar siswa meningkat dengan nilai rata-rata 83,85 . Berdasarkan hasil penelitian tersebut dapat disimpulkan bahwa terdapat peningkatan hasil belajar dengan menggunakan e-modul.

Dalam kurikulum 2013 salah satu model yang dapat digunakan dalam proses pembelajaran adalah model problem based learning. Siswa mencari pengetahuan bukan menerima pengetahuan, oleh karenanya alternatif pembelajaran yang efektif digunakan adalah berbasis problem based learning. Pembelajaran berbasis masalah yang dikenal dengan model problem based learning sangat tepat digunakan dalam membantu siswa dalam proses pembelajaran.

Penerapan model PBL efektif untuk meningkatakan kemampuan berpikir kritis siswa dan hasil belajar siswa. Model PBL diharapkan lebih baik untuk meningkatkan keaktifan siswa dan dapat menuntut siswa agar lebih berpikir kritis jika dibandingkan dengan model pembelajaran konvensional. Oleh sebab itu e-module berbasis problem based learning, mampu menciptakan keaktifan siswa dalam proses pembelajaran, mengembangakan keterampilan berfikir serta keterampilan pemecahan masalah. Berdasarkan permasalahan di atas maka, penulis ingin mengembangkan sebuah modul pembelajaran ekonomi berbentuk elektronik berbasis problem based learning. E-module pembelajaran yang dikembangkan adalah e-modul pembelajaran ekonomi pada materi konsep manajemen dan disajikan melalui media elektronik dan yang dapat digunakan melalui computer, laptop, dan juga smartphone. Oleh karena itu, penulis tertarik untuk melakukan penelitian dengan judul: "Pengembangan E-Module Berbasis Problem 
Pebri Hastuti, Roza Thohiri, Yanti Panggabean. Pengembangan E-Module Berbasis Problem Based Learning Mata Pelajaran Ekonomi Kelas X SMA Negeri 1 Percut Sei Tuan Tahun Ajaran 2018/2019

Based Learning Mata Pelajaran Ekonomi Kelas X SMA Negeri 1 Percut Sei Tuan Tahun Ajaran 2018/2019".

\section{METODE}

Penelitian ini dilaksanakan di SMA Negeri 1 Percut Sei Tuan yang berlokasi di jalan Irian Barat Sampali No.37 Percut Sei Tuan, Deli Serdang. dilaksanakan pada semester genap tahun pembelajaran 2018/2019. Adapun subjek penelitian ini adalah siswa kelas X IPS SMA Negeri 1 Percut Sei Tuan yang berjumlah 35 orang. Kemudian, objek dalam penelitian ini adalah pengembangan emodule pembelajaran ekonomi berbasis problem based learning pada mata pelajaran ekonomi.

Metode penelitian yang digunakan peneliti adalah metode penelitian dan pengembangan Research and Development (R\&D). Penelitian ini adalah penelitian yang digunakan untuk menghasilkan produk tertentu, dan menguji keefektifan produk tersebut (Sugiyono, 2010: 297).

Pada penelitian ini akan mengembangkan suatu produk berupa e-module berbasis problem based learning mata pelajaran ekonomi. Model pengembangan yang digunakan untuk mengembangkan e-module adalah model ADDIE yang dikembangkan oleh Dick and Carry (1996) untuk merancang sistem pembelajaran. Adapun tahapan penelitian penggembangan model ADDIE yaitu: (1) Analisis (Analysis), (2) Desain/ perancangan (Design), (3) Pengembangan (Development), (4) Implementasi (Implementation), dan (5) Evaluasi/ umpan balik (Evaluation). Model ADDIE dikembangkan untuk merancang sistem pembelajaran (Mulyatiningsih, 2013).

\section{HASIL DAN PEMBAHASAN}

\subsection{Deskripsi Tahap Analisis (Analysis) 3.1.1. Analisis Kurikulum}

Pada tahapan ini, analisis kurikulum yang dilaksanakan pada kelas X SMA Negeri 1 Percut Sei Tuan adalah Kurikulum 2013. Kurikulum 2013 bertujuan untuk mendorong peserta didik lebih mampu melakukan observasi, bertanya, bernalar serta mempersentasikan apa yang diperoleh atau diketahui setelah menerima materi pelajaran. Kurikulum 2013 merujuk pada partisipasi murid secara aktif baik secara fisik, mental, intelektual dan emosional, yang diharapkan akan menghasilkan siswa yang poduktif, kreatif, inovatif, dan efektif.
Siswa secara aktif membentuk pengetahuannya sendiri.

Selain menerapkan Kurikulum 2013, sekolah ini juga terpilih menjadi salah satu sekolah rujukan sehingga dianjurkan menggukan e-module saat proses pembelajaran. Beberapa guru bidang studi tertentu telah menerapkan penggunaan e-module dalam proses pembelajaran didalam kelas, alasannya selain untuk menambah bahan ajar siswa juga lebih antusias belajar dengan menggunakan e-module. Oleh karena itu peneliti juga menerapakan hal yang sama. E-module ekonomi yang peneliti kembangkan menggunakan aplikasi yang sama dengan e-module yang biasa digunakan sehingga siswa tidak perlu kewalahan dengan aplikasi yang baru.

\subsubsection{Analisis kegiatan Pembelajaran}

Pada tahap ini peneliti memperoleh data tentang kondisi kegiatan pembelajaran yang selama ini terjadi. Kegiatan pembelajaran di kelas dimulai dengan guru menerangkan dan mendemonstrasikan materi di depan kelas, kemudian siswa mendengarkan, mencatat, dan mengerjakan tugas sesuai dengan perintah guru. Pembelajaran yang dilakukan cenderung berpusat pada guru. Proses pembelajaran berdurasi $3 \times 45$ menit dalam satu kali pertemuan, namun pemanfaatan waktu pembelajaran masih kurang maksimal

\subsubsection{Analisis Penggunaan Bahan Ajar}

Adapun bahan ajar yang digunakan guru pada saat proses pembelajaran sebelumnya adalah buku paket dari pemerintah atau dari dana BOS. Guru bidang studi tidak memiliki buku pegangan lain. Demikian juga halnya dengan siswa, hanya diberikan buku paket dari dana BOS pada saat pembelajaran. Satu buku paket digunakan oleh 2 orang siswa. Hal inilah yang menimbulkan kurangnya pemahaman siswa pada materi yang disampaikan dan ketergantungan siswa hanya pada perintah guru sehingga dinilai kurang mandiri dalam belajar. Guru bidang studi menyatakan perlunya dikembangkan bahan ajar yang lebih menarik, dapat memperjelas materi yang disampaikan, dan memudahkan siswa memahami materi secara mandiri

\subsection{Deskripsi Tahapan Desain (Design)}

Tahap desain merupakan tahap perancangan emodule dengan menggunakan aplikasi Sigil. Apalikasi Sigil adalah sebuah aplikasi untuk manajemen dan pembuatan e-module dengan format epub. Langkah pertama dalam pebuatan e-module ini terlebih dahulu peneliti menginstal softwere Sigil di 
http://www.downloaddcrew.com/article/23796 -1sigil_32-bit.

\subsection{Deskripsi Tahap Pengembangan (Development)}

\subsubsection{Pengembangan $E$-Module}

Awalnya materi dan soal-soal pada e-module dibuat dengan menggunakan aplikasi Microsoft Office Word 2010. Sebelumnya file materi yang disimpan di Microsoft Office Word harus diubah ke dalam format web page, filtered sehingga nantinya dapat dikembangkan dengan aplikasi Sigil yang telah diinstal. Pembuatan cover, daftar isi, pengaplotan video dan lain sebagainya dibuat dengan menggunkan Sigil epup 2.0.

\subsubsection{Pengembangan Instrumen}

Instrumen yang sudah dirancang pada tahap desain, selanjutnya disusun dan dikonsultasikan pada dosen pembimbing. Instrument penilaian digunakan untuk mengukur kelayakan e-module. Validator instrumen penilaian oleh dosen adalah bapak Dr.Janner Simarmata, ST, M.Kom, ibu Dita Eka Pertiwi Sirait, SE, M.Si dan ibu Pebri Hastusi, S.Pd, M.Pd. Validator instrumen penilaian oleh guru bidang studi adalah ibu Desnawati Ginting S.Pd

\subsection{Deskripsi Tahap Implementasi (Implementation)}

\subsubsection{Uji Coba E-Module}

Setelah e-module divalidasi oleh ahli dan sudah diperbaiki, e-module diuji cobakan kepada siswa kelas $\mathrm{X}$ SMA Negeri 1 Percut Sei Tuan dengan jumlah siswa sebanyak 35 orang. E-module pada sigil dapat dibaca menggunakan Calibre atau Readium, yang merupakan perangkat tambahan dari aplikasi sigil yang dapat membaca format file epub. Implementasi $e$-module sigil dibaca memalui readium. Pada Uji coba ini dilakukan di kelas X IPS-2. Hasil uji coba akan dijadikan sebagai acuan dalam perbaikan/revisi $e$-module yang dikembangkan.

\subsubsection{Hasil Angket Respon Siswa}

Hasil penilaian respon siswa terhadap e-module pada angket yang sudah diisi diperoleh rata-rata keseluruhan skor penilaian sebesar 3,52 dari skor maksimal 4,00 dengan kategori produk sangat baik.

\subsubsection{Hasil Belajar Siswa}

Hasil belajar siswa disajikan pada tabel 4.5 Berdasarkan perolehan hasil belajar siswa menggunakan e-module dapat dianalisis bahwa secara individu 31 orang siswa yang tuntas belajar dengan perolehan nilai $\geq 80$ dan secara klasikal hasil belajar siswa berada pada $86-100 \%$ masuk dalam kriteria keberhasilan sangat tinggi

\subsection{Deskripsi Tahap Evaluasi (Evaluation)}

Tahap evaluasi ini digunakan untuk melihat tindaklanjut yang telah peneliti lakukan atas saran yang diterima dari setiap ahli.

\section{KESIMPULAN}

4.1. Penelitian pengembangan ini menghasilkan produk bahan ajar berupa e-module berbasis problem based learning pada mata pelajaran Ekonomi untuk kelas X SMA Negeri 1 Percut Sei Tuan Tahun Ajaran 2018/2019. Penelitian ini mengacu pada model pengembangan ADDIE dengan tahapan Analysis, Design, Development, Implementation, dan Evaluation.

4.2. Hasil penelitian yang diperoleh menunjukkan bahwa e-module yang dikembangkan valid (layak), efektif dan praktis digunakan sebagai bahan ajar untuk guru dan siswa dalam proses kegiatan pembelajaran berdasarkan perolehan nilai rata-rata keseluruhan skor aspek oleh ahli materi 3,46 kategori sangat baik, rata-rata keseluruhan skor aspek oleh ahli media 3,19 kategori sangat baik, dan rata keseluruhan skor aspek oleh respon siswa terhadap e-module 3,29 kategori sangat baik.

4.3. Evaluasi siswa menunjukkan hasil presentase keberhasilan sebesar $88,6 \%$ yang masuk pada kategori kriteria keberhasilan tinggi pada pengerjaan evaluasi akhir materi Konsep Manajeman.

\section{DAFTAR PUSTAKA}

Darmawan, Deni. 2014. Teknologi dan informasi. Bandung: PT. Remaja Rosdakarya.

Daryanto. (2013). Menyusun Modul. Yogyakarta : Gava Media

Dick, W. and Carey, L. (1990). The Systematic Design of Instruction. (Third ed.). United States of America : Harper Collins Publishers.

Dwiki, dkk. 2014. Pengembangan E-Modul Dengan Model Problem Based Learning Pada Materi Bilangan Bulat Kelas VII. Jurnal Pendidikan Ekonomi. Vol. 14/no.2/2014.

Evi, dkk. 2018. Pengembangan E-Modul Pembelajaran Ekonomi Materi Pasar Modal Untuk Siswa Kelas XI IPS MAN 1 Jember Tahun Ajaran 2016/2017. Jurnal Pendidikan Ekonomi. Vol. 12/no.2/2018.

Cleary, M. (2019). 済無No Title No Title. In Journal of Chemical Information and Modeling (Vol. 53, Issue 9). https://doi.org/10.1017/CBO9781107415324.004

Hastuti, P., Irianto, A., \& Izzati, T. (2015). FACTORS THAT AFFECT LEARNING DIFFICULTIES OF SUBJECTS RELATED TO ECONOMICS FOR 
Pebri Hastuti, Roza Thohiri, Yanti Panggabean. Pengembangan E-Module Berbasis Problem Based Learning Mata Pelajaran Ekonomi Kelas X SMA Negeri 1 Percut Sei Tuan Tahun Ajaran 2018/2019

THE FIRST YEAR SENIOR HIGH SCHOOL IN THE BOARDING SCHOOLS , PADANG PANJANG - WEST SUMATERA May-June. 27(3), 2477-2479.

Hutasuhut, S., \& Syahfitri, I. (2018). Jurnal Ekonomi Pendidikan Volume 7: Nomor 5 Juni 2018 PENGARUH GAYA BELAJAR TERHADAP PRESTASI BELAJAR SISWA Jurnal Ekonomi Pendidikan Volume 7: Nomor 5 Juni 2018 PENDAHULUAN Salah satu tujuan nasional bangsa Indonesia yang tertera dalam Undang Undang Da. 7, 1-8.

Nelvy, dkk. 2015. Pengembangan E-Module Ekonomi Pada Materi Uang Dan Perbankan Untuk Siswa Kelas X A SMA Negeri 1 Panggul Trenggalek Tahun Ajaran 2014/2015. Jurnal Pendidikan Ekonomi. Vol. 8/no.1/2015.

Mulyatiningsih, Endang. 2013. Metode Penelitian Terapan Bidang Pendidikan. Bandung: Alfabeta.

Sugiyono. 2016. Metode Penelitian Kuantitatif, Kualitatif, R\&D. Bandung: Alfabeta

Komang, dkk. 2017. Pengembangan E-Modul Berbasis Model Pembelajaran Discovery Learning Pada Mata Pelajaran "Sistem Komputer" Untuk Siswa Kelas X Multimedia SMK Negeri 3 Singaraja. Jurnal Pendidikan Teknologi dan Kejuruan. Vol. 14/no.1/2017. 